\title{
Verkko-oppimisympäristöjen kehittäminen tekoälyn avulla: Tulevaisuusvisio matematiikan opetuksen täydennyskoulutuksesta
}

\author{
Mika Koponen ${ }^{1}$, Anni Sydänmaanlakka² ja Erika Löfström² \\ ${ }^{1}$ Kasvatustieteiden ja kulttuurin tiedekunta, Tampereen yliopisto \\ ${ }^{2}$ Kasvatustieteellinen tiedekunta, Helsingin yliopisto
}

Verkko-oppimisympäristöjen suosio kasvaa kiihtyvällä tahdilla maailman laajuisesti ja samaan aikaan tarve uusille lähestymistavoille verkko-oppimisen ja -opetuksen kehittämisessä ja tutkimuksessa on kasvanut. Vaikka lokitiedot mahdollistavat verkkokäyttäytymisen tutkimisen, on tätä mahdollisuutta hyödynnetty verkkooppimisen ja -opetuksen tutkimuskontekstissa verrattain vähän. Tutkimuksessa hyödynnettiin lokitietoja verkkokurssin arvioinnissa ja kehittämisessä MOOCympäristössä. Tässä artikkelissa kuvataan oppimisprosessia lokitietojen avulla sekä pohditaan sitä, minkälaista ymmärrystä oppimisesta lokitiedot voivat tuottaa ja miten tällaisen tiedon voisi tulevaisuudessa valjastaa oppimisen tueksi. Tutkimusaineisto koostui matematiikan opettajien ( $N=58)$ täydennyskoulutusverkkokurssin lokitiedoista. Tutkimustulokset osoittavat, että syvällisemmät tai enemmän aikaa vaativat aktiviteetit keskeyttävät yhtenäisen opiskelun herkemmin kuin esimerkiksi videoluennot. Lyhytkestoiset videot ja nopeasti vastattavat kyselyt sen sijaan sitouttavat osallistujia yhtenäiseen opiskeluun. Vaikka suoristustavoissa on yksilöllisiä eroja, verkkokurssin kehittämistarvetta on mahdollista arvioida lokitietojen avulla. Esitämme artikkelissa vision siitä, kuinka tulevaisuudessa lokitiedot voisivat automaattisesti analysoitua, järjestelmä tunnistaisi oppimisprofiileja ja verkko-oppimisympäristö muokkautuisi automaattisesti tunnistettujen opiskelutaipumusten mukaan. Kun prosessiin yhdistetään tekoäly myös profilointialgoritmi kehittyisi automaattisesti käyttäjädatan kasvun myötä.

Avainsanat: täydennyskoulutus, verkko-oppiminen, lokitiedot, käyttäjädata, tekoäly 


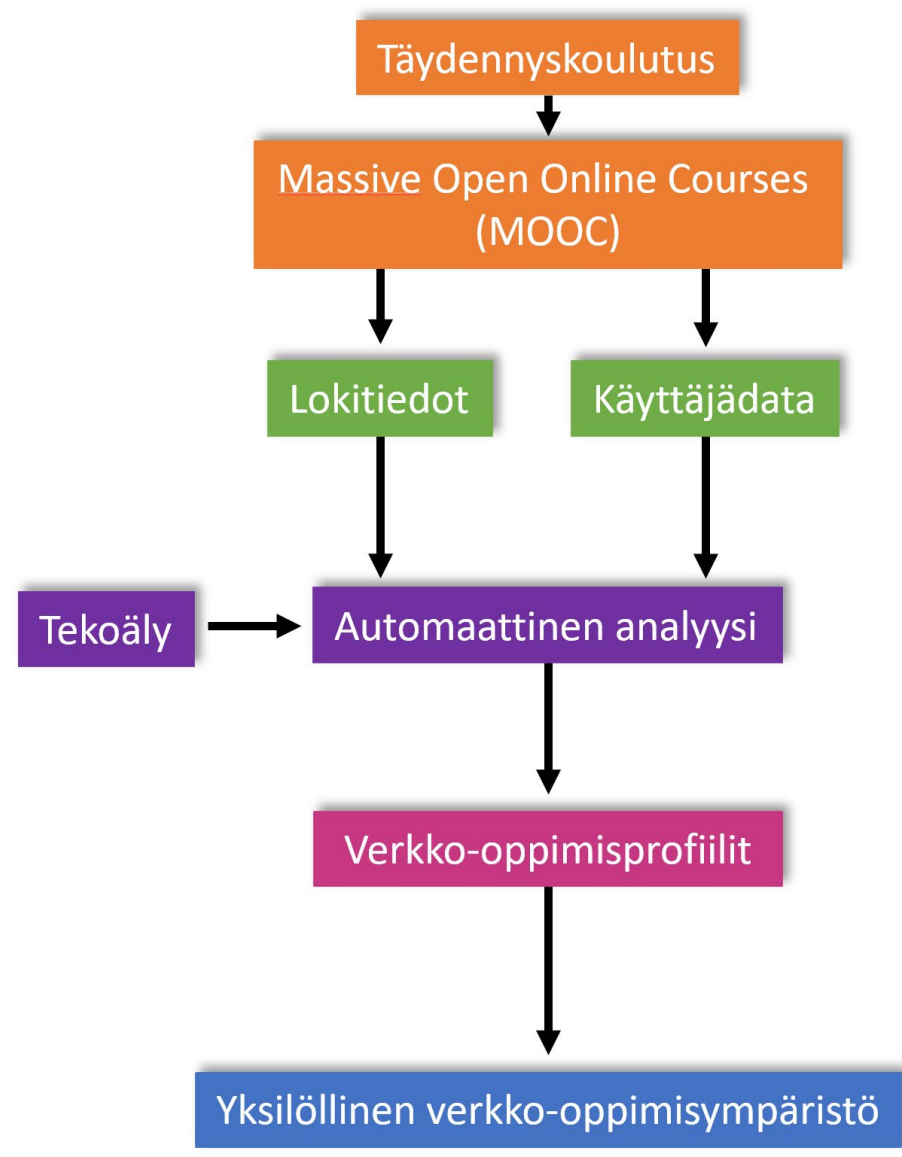

\section{Opettajien täydennyskoulutus verkossa}

Laajat kansainväliset tutkimukset osoittavat, että opettajien saamalla koulutuksella on yhteys heidän tiedolliseen osaamiseensa (Schmidt, Houang \& Cogan, 2011). Kouluttautumisen myötä opettajien matemaattinen ja pedagoginen osaaminen kasvaa, opetus kehittyy ja matematiikan oppimistulokset paranevat myös koulutasolla. Esimerkiksi matematiikan osaamisen TIMSS ${ }^{1-t u l o k s e t ~ o v a t ~ k o r k e a m p i a ~}$ niissä maissa, joissa opettajien matemaattinen ja pedagoginen osaaminen (arvioituna matematiikan tehtävien ja matematiikan opetukseen liittyvien tilannearvioiden kautta) on korkeampaa (Schmidt, Houang \& Cogan, 2011). Matematiikan perus- ja täydennyskoulutuksen vaikutukset ulottuvat siis koulutasolle saakka (Blömeke, Busse, Kaiser ym., 2016; Kaiser \& König, 2019). Vaikka laajat kansainväliset opettajankoulutusohjelmien vertailututkimukset tuottavat tietoa

\footnotetext{
${ }^{1}$ Laajassa kansainvälisessä TIMSS-tutkimuksessa (Trends in International Mathematics and Science Study) arvioitiin kahdeksannen luokan oppilaiden matematiikan osaamista.
} 
opettajankoulutusohjelmien eroista (Schmidt, Houang \& Cogan, 2011), opettajien perus- ja täydennyskoulutuksen kehittämiseen tarvitaan kuitenkin tutkimusperustaista tietoa koulutusohjelman vaikuttavuudesta (Hsieh, Law, Shy ym. 2011).

Verkko-oppiminen on mullistanut täydennyskoulutuksen kenttää merkittävästi (Cheng ym., 2014). Koulutusmuotojen monipuolistamiseksi verkkoympäristöjä on kehitetty jo vuosikymmeniä myös opettajankoulutuksen tarpeisiin. Vastaavaa työtä tehdään nyt myös Suomessa täydennyskoulutustarjonnan kehittämiseksi. Opetushallitus on rahoittanut vuosina 2018-2022 toteuttavia kehittämishankkeita, joiden tavoitteena on viedä matematiikan opetuksen täydennyskoulutusta verkkoympäristöön. Verkkokurssit ovat helposti saatavilla ympäri vuorokauden sijainnista riippumatta ja ne tarjoavat uudenlaisia oppimismahdollisuuksia, joten verkko-opetusmuodon toivotaan aktivoivan myös niitä opettajia, jotka eivät aktiivisesti osallistu täydennyskoulutuksiin. Heitä on opettajakunnassa noin viidennes opettajista (Lavonen \& Mahlamäki-Kultanen, 2016).

Verkko-opetukseen liittyy kuitenkin haasteita. Esimerkiksi Massive Open Online Course (MOOC) -verkkokursseille osallistujia voi olla määrällisesti lähes rajattomasti. Kansainvälisissä tutkimuksissa verkkokurssien osallistujamäärät ovatkin varsin suuria, mutta samaan aikaan keskeyttäneiden osuus on tyypillisesti noin $90 \%$ (Nawrot \& Doucet, 2014). Myös verkkokurssien opettajat kohtaavat uudenlaisia haasteita, sillä verkkokursseilla yksilöllisten erojen huomiointi tai sosiaalisen vuorovaikutuksen vahvistaminen on haastavaa (Terras \& Ramsay, 2015; Yu, 2015). Verkko-oppimiskokemusta heikentää osallistujan kielteinen asenne teknologiaa kohtaan (Rogers, 2000), heikot tietotekniset taidot (Berge, 2002, Mailizar, Abdulsalam \& Suci, 2020), teknologisten välineiden heikko saatavuus (Brzycki \& Dubt, 2005), tuen puute (Muilenburg \& Berge, 2005) ja tietotekniset ongelmat (Ali \& Magalhaes, 2008). Toisaalta verkkokurssien etuina voidaan pitää esimerkiksi sitä, että verkkokurssit ovat saatavilla missä ja milloin vain, verkkokurssit ovat kustannustehokkaita ja oppijan on helppo palata opetussisältöihin uudelleen (Yu, 2015). Erityisesti opettajien täydennyskoulutuksessa MOOCeista on saatu lupaavaa näyttöä odotusten toteutumisen ja relevanssin suhteen (Herranen, Aksela, Kaul \& Lehto, 2021).

Vaikka verkko-opetukseen liittyy monia haasteita, voidaan verkossa nähdä myös uudenlaisia mahdollisuuksia oppimiseen. Yi-Shun Wang (2003) on esittänyt verkkokurssilla vaikuttavien tekijöiden teoreettisen mallin, jonka mukaan tekninen 
rajapinta ja sen ominaisuudet, oppijayhteisö, oppisisältö ja mahdollisuudet oppimisen yksilöllistämiseen muodostavat oppimiskokemusta kuvaavan kokonaisuuden. Näillä tekijöillä on yhteys oppijan kurssityytyväisyyteen ja niillä oletetaan myös olevan yhteys verkkokurssin jälkeiselle toiminnalle (Wang, 2003). Täydennyskoulutuksen vaikuttavuuden näkökulmasta kiinnostavaa on se, kuinka hyvin verkkokoulutus vastaa yksittäisen opettajan ammatillisiin odotuksiin, kehittymistarpeisiin ja kuinka koulutuksesta saadut uudet opetusideat siirtyvät käytäntöön (Chen, 2010; Herranen ym., 2021). Juuri kokemus siitä, että verkkokurssilla opitusta sisällöstä on hyötyä esimerkiksi työtehtävien kannalta, on keskeistä verkkokurssin loppuun suorittamisessa (Rodríguez-Ardura \& MeseguerArtola, 2016). Esimerkiksi Lun ja Chioun (2010) tutkimuksessa työssäkäyvät opiskelijat suhtautuivat kurssisisältöihin kriittisemmin kuin täysipäiväiset opiskelijat, mikä viittaa siihen, että opiskeltavan sisällön relevanssia punnitaan työssähyödynnettävyyden näkökulmasta (ks. myös Herranen ym., 2021).

Verkkoympäristössä oppimateriaali kuuluu keskeisesti oppimiskokemusta muovaaviin tekijöihin (Wu \& Lin, 2012). Verkkokursseilla opetussisältöihin tulisi kiinnittää enemmän huomiota, ehkä jopa enemmän kuin ympäristön suunnitteluun sinänsä (Papachristos ym., 2014). Kokemus verkkokurssin hyödyllisyydestä näyttäisi syntyvän nimenomaan merkitykselliseksi koetun sisällön eikä kurssiympäristön kautta, joskin oppimisympäristön käyttäjäystävällisyys on oppimiskokemukseen vaikuttava tekijä ( $\mathrm{Lu} \&$ Choiu, 2010). Oppijan tunne siitä, että hän pystyy hallitsemaan oppimisympäristöään ja kykenee hyödyntämään vuorovaikutuksen välineitä kommunikoidakseen oppimisympäristössä edistävät niin ikään myönteisiä oppimiskokemuksia (Rodríguez-Ardura \& Meseguer-Artola, 2017).

Vaikka verkkokurssit tarjoavat väylän myös suomalaisen täydennyskoulutustarjonnan monipuolistamiseen, uuden äärellä tarvitaan tutkimustietoa verkossa tapahtuvan täydennyskoulutuksen vaikuttavuudesta. Usein valtaosa tutkimusresursseista suuntautuu opettajien peruskoulutuksen vahvistamiseen, jolloin täydennyskoulutuksien tutkimusperustaista kehittämistyötä tehdään huomattavasti vähemmän (Wang, Wang \& Shee, 2007; Chen, 2010). Koska verkkokurssit saattavat aktivoida myös niitä opettajia, jotka eivät perinteiseen täydennyskoulutukseen osallistu, voivat täydennyskoulutuksen haasteet olla moninaisempia. Esimerkiksi tutkimuksen kohteena olevassa täydennyskoulutusohjelmassa joka kolmas opettaja osallistui verkossa tapahtuvaan täydennyskoulutukseen ensimmäistä kertaa (Löfström ym. 2021). Opettajat kokivat 
myös, että arjen kiire ja ajanpuute ovat keskeisimpiä syitä siihen miksi täydennyskoulutuksen opit eivät päädy kouluopetukseen.

Tässä tutkimuksessa pureudutaan siihen, kuinka opettajat suorittavat täydennyskoulutusverkkokurssia ajallisesti. Tutkimuksessa analysoimme verkkotehtävien suoristusmääriä, -aikoja ja -ajankohtia. Verkkokurssin oppimisympäristöön tallentuvista lokitiedoista selvitämme yksilöllisesti kurssipudokkuutta (verkkokurssin aikana tehtyjen tehtävien lukumäärä), kurssikuormitusta (verkkokurssiin käytetty kokonaisaika), tehtäväkuormitusta (yksittäiseen tehtävään käytetty keskimääräinen aika), kiinnittymistä (yhdellä kirjautumiskerralla tehtyjen tehtävien lukumäärä) ja yhtenäistä opiskeluaikaa (yhdellä kirjautumiskerralla verkkoympäristössä käytetty kokonaisaika). Näihin tietoihin perustuen vastaamme tutkimuskysymyksiin:

1. Millainen on opettajien oppimisprosessi matematiikan opetuksen täydennyskoulutusverkkokurssilla ajallisesta, kurssi- ja tehtäväkuormituksen sekä tehtäviin kiinnittymisen näkökulmasta?

2. Millaisia yksilöllisiä eroja opettajien ajankäytössä, kuormituksessa ja tehtäviin kiinnittymisessä on matematiikan opetuksen täydennyskoulutusverkkokurssin suorittamisessa?

Koska opetussisällöillä ja oppimateriaaleilla on vaikutus verkko-oppimiseen $(\mathrm{Wu}$ \& Lin, 2012; Papachristos ym. 2014), analysoimme myös sitä, kuinka opetussisältö ja erilaiset verkkotehtävätyypit (ohje, video, kysely ja keskustelu, pohdinta tai soveltava tehtävä) vaikuttavat verkko-opiskelun yhtenäisyyteen. Tarkastelemme erityisesti verkko-opiskelun keskeytysten suhdetta annettuihin verkkotehtäviin. Kolmas tutkimusta ohjaava kysymys on

3. Kuinka koulutuksen opetussisältö ja verkkotehtävätyypit vaikuttavat verkkoopiskelun yhtenäisyyteen?

Hypoteesimme mukaan kuhunkin tehtävään käytetystä opiskeluajasta on mahdollista tunnistaa esimerkiksi sellaiset videot, joita ei tyypillisesti katsota kokonaan tai tehtävät, joita ei varsinaisesti pohdita vaan vastaus annetaan heti. Koska analyysistä saatavia tuloksia voidaan verrata eri verkkotehtävien tavoitteisiin, on 
koulutuksen järjestäjän mahdollista arvioida ovatko verkkotehtäviin käytetyt opiskeluajat tarkoituksenmukaisia. Näin analyysistä saatava tieto auttaa koulutuksen järjestäjää arvioimaan verkkokurssin kehittämistarvetta. Toteutetun tutkimuksen innoittamana esitämme lopuksi vision tulevaisuuden verkko-oppimisympäristöstä, jossa järjestelmä analysoisi automaattisesti oppijoiden opiskelutaipumuksia, muodostaisi niistä oppimisprofiileja ja muokkaisi verkkoympäristöä yksilöllisesti tunnistettujen opiskelutaipumusten mukaan oppimista paremmin tukevasi. Kun prosessia kehitettäisi tekoälyn avulla, käyttäjädatan kasvu parantaisi oppijoiden profilointia ja johtaisi yhä älykkäämpiin verkkoympäristön yksilöllistämisratkaisuihin. Tekoäly on jo muuttanut verkko-oppimisen yksilöllistämistä tukevia ratkaisuja (Roll \& Wylie, 2016), mutta suomalaisessa opettajien täydennyskoulutuskontekstissa tätä on pohdittu toistaiseksi vähemmän.

\section{Verkkotäydennyskoulutus kehittämistutkimuksen kohteena}

Tutkittavaa matematiikan opetuksen täydennyskoulutusta on kehitetty kehittämistutkimuksen menetelmällä. Kehittämistutkimuksen strategia etenee siten, että ensin koulutusta arvioidaan, mikä avulla tunnistetaan koulutuksen haasteet ja lopuksi tunnistetuille haasteille etsitään ratkaisua kehittämisen kautta (Kuva 1). Kehittämistutkimusta on hyödynnetty erityisesti teknologiavälitteisissä koulutuskonteksteissa, ja se soveltuu strategiaksi myös koulutusohjelmien kehittämiseen matematiikan opetuksen kontekstissa (Wood \& Berry 2003). Kehittämistutkimus on luonteeltaan iteratiivista ja tuottaa jatkuvasti uutta tietoa koulutusohjelman kehittämiseen (Amiel \& Reeves, 2008; Kervinen ym., 2016). Kehittämistutkimus soveltuu siten myös käynnissä olevien koulutusohjelmien kehittämiseen. Wood ja Berry (2003, p. 197) kuvaa strategiaa osuvasti: kehittämistutkimus on kuin "lentäisi lentokoneella ja korjaisi sitä samaan aikaa".

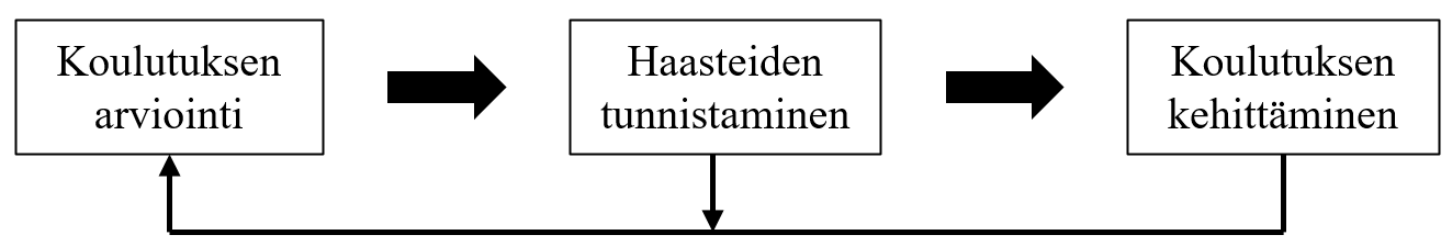

Kuva 1. Kehittämistutkimus arviointiperustaisena ja iteratiivisena prosessina 
Tutkimuksen aiemmassa vaiheessa täydennyskoulutuksen vaikuttavuutta arvioitiin kyselytutkimuksen avulla, jonka tuloksena osallistujien aikahaasteet ja niiden moninaisuus nousivat esille (Koponen, Löfström \& Portaankorva-Koivisto, 2020). Kun koulutukseen osallistuneilta opettajilta kysyttiin, millaiset tekijät estävät heitä viemästä koulutuksesta opittuja asioita käytäntöön, nosti 60 \% opettajista esiin työhön liittyvän kiireen ja ajanpuutteen (Koponen, Löfström \& PortaankorvaKoivisto, 2020). Koska koettu kiire ja ajanpuute saattavat vaikuttaa myös verkkokurssien suorittamiseen, tässä tutkimuksessa on pureuduttu tarkemmin siihen, miten osallistujat käyttävät aikaansa ja miten he toimivat verkkooppimisympäristössä. Kehittämistutkimukselle ominaista on juuri se, että tunnistetut haasteet toimivat lähtökohtana koulutuksen jatkoarviointiin tai -kehittämiseen. Myös vaiheiden mukainen raportointi on ominaista kehittämistutkimukselle (Juuti \& Lavonen, 2006).

Kehittämistutkimukselle tyypillistä on, että se toteutetaan aidossa koulutuksellisessa kontekstissa (Anderson \& Shattuck, 2012). Tutkittavassa täydennyskoulutusohjelmassa verkkokurssit itsessään muodostavat opetuksellisen intervention, jota kehitetään osapuolilta saadun palautteen perusteella (vrt. Anderson \& Shattuck, 2012). Kehittäminen on usein iteratiivinen prosessi, jossa kehittämisen kohteena oleva interventio hioutuu sitä mukaan, kun sen toimivuudesta saadaan lisää tietoa. Tutkimuksen kohteena oleva täydennyskoulutusverkkokurssi on toteutettu jo kymmeniä kertoja, mutta lokitietojen tarkastelu tuli ajankohtaiseksi vasta kyselytutkimuksen nostettua esille osallistujien kokemat aikahaasteet.

Usein kehittämistutkimuksen kimmokkeena on jokin jännite, haaste (Wang \& Hannafin, 2005) tai muutokset toimintaympäristössä (Juuti \& Lavonen, 2006). Yhtenä motiivina on esitetty oppimisnäkemyksen ja sen käytännön toteutuksen väliset ristiriidat juuri verkko-oppimiskontekstissa (Wang \& Hannafin, 2005). Tutkittavassa täydennyskoulutusohjelmassa jännitteen aiheutti osallistujien kokemat arjen aikahaasteet (Koponen, Löfström \& Portaankorva-Koivisto, 2020) ja toisaalta koulutuksen järjestäjien epätietoisuus siitä, kuinka kuorimittavia tai aikaa vieviä verkkokurssin tehtävät ovat. Tunnistettu haaste voikin siis toimia koulutuksen kehittämisen lähtökohtana tai käynnistää koulutuksen jatkoarvioinnin (Kuva 1).

Kehittämistutkimusprosessin tuloksena syntyvä pedagoginen tieto valjastetaan sekä teoreettisen tiedon lisäämiseen että käytäntöjen kehittämisen (Juuti \& Lavonen, 2006). Tutkimuksen tavoitteena on tuottaa tietoa täydennyskoulutukseen 
osallistuvien toiminnasta verkkoympäristössä ja sitä kautta antaa välineitä kehittää koulutusta osallistujia paremmin palvelevaan muotoon.

\section{Menetelmä}

\subsection{Konteksti}

Tutkimuksen aineisto kerättiin matematiikan opetuksen LUMATIKKAtäydennyskoulutusohjelmasta. LUMATIKKA on Helsingin yliopiston järjestämä ja Opetushallituksen rahoittama täydennyskoulutusohjelma varhaiskasvatuksesta toiselle asteelle työskenteleville opettajille. Täydennyskoulutusohjelma (15 op $\left.^{2}\right)$ koostui kaikkien luokka-asteiden opettajille yhteisestä osasta (3 op), luokkaastekohtaisesta osasta (6 op), sekä valinnaisesta osasta (6 op). Koulutuksen ensimmäisen osan tavoitteena oli kehittää laaja-alaisesti osallistujien matemaattista ja pedagogisia osaamista, toisessa osassa syvennyttiin opetusastekohtaiseen didaktiikkaan ja kolmannessa osassa osallistujan oli mahdollista valita verkkokurssi tarkempaan teemaan liittyen kuten esimerkiksi, kuinka yhdistää ohjelmointi, taide tai liikunta matematiikan opetukseen. Taustalla on sosiokonstruktivismiin pohjautuva näkemys oppimisesta.

Tämän tutkimuksen aineisto kerättiin koulutusohjelman ensimmäisestä osasta. Tutkimuksen kohteena oleva verkkokurssi sisälsi teoreettisen ja soveltavan osan, joiden opetussisällölliset teemat on kuvattu Taulukossa 1. Teoriaosuuden ensimmäinen teema esitteli aiempaa tutkimustietoa suomalaisten oppilaiden matematiikan osaamiseen liittyen. Seuraavat viisi teemaa keskittyivät matemaattisiin taitoihin, niiden tukemiseen sekä niihin vaikuttaviin tekijöihin. Kolme seuraavaa teemaa käsitteli ongelmalähtöisen matematiikan opetuksen toteuttamista.

\footnotetext{
${ }^{2}$ Laskennallisesti yksi opintopiste (op) vastaa noin 27 tunnin työpanosta.
} 
Taulukko 1. Verkkokurssin opetussisällöt teemoittain

\begin{tabular}{|c|c|c|}
\hline & Teema & Opetussisältö \\
\hline \multirow[t]{9}{*}{ Teoriaosa } & $\begin{array}{l}\text { Tutkimustietoa } \\
\text { matematiikan } \\
\text { osaamisesta }\end{array}$ & $\begin{array}{l}\text { Matematiikan oppimistuloksia kansainvälisissä ja } \\
\text { kansallisista tutkimuksissa }\end{array}$ \\
\hline & \multirow{5}{*}{$\begin{array}{l}\text { Matemaattiset taidot ja } \\
\text { niiden tukeminen }\end{array}$} & Matematiikan perustaidot \\
\hline & & Matematiikan oppimisvaikeudet \\
\hline & & Kielitietoinen matematiikan opetus \\
\hline & & $\begin{array}{l}\text { Matematiikan oppiminen aivotutkimuksen } \\
\text { näkökulmasta }\end{array}$ \\
\hline & & Motivaation merkitys oppimiseen \\
\hline & \multirow{3}{*}{$\begin{array}{l}\text { Ongelmalähtöinen } \\
\text { matematiikan opetus } \\
\text { (teoriassa) }\end{array}$} & Ongelmanratkaisutaidot matematiikan opetuksessa \\
\hline & & Tutkivan oppimisen tukeminen opetuksessa \\
\hline & & Oppimateriaalien erilaiset käyttömahdollisuudet \\
\hline Soveltavaosa & $\begin{array}{l}\text { Ongelmalähtöinen } \\
\text { matematiikan opetus } \\
\text { (käytännössä) }\end{array}$ & $\begin{array}{l}\text { Ongelmalähtöisen opetuskokeilun suunnittelu, } \\
\text { toteutus ja raportointi }\end{array}$ \\
\hline
\end{tabular}

Verkkokurssin suoritus rakentui erilaisten tehtävien suorituksista (Taulukko 2). Jokainen opetussisältöteema sisälsi vähintään yhden videoluennon ja tehtäväaktiviteetin. Esimerkiksi teoriaosuudessa osallistuja katsoi videoluentoja opetussisältöteemaan liittyen, jonka päätteeksi osallistujaa pyydettiin vastaamaan Testaa tietosi -kyselyyn. Kysely sisälsi videoihin liittyviä väittämiä, joihin hyväksytty suorittaminen vaati $80 \%$ tarkkuuden. Videoluentojen ja kyselyiden lisäksi verkkokurssi sisälsi keskustelu- ja pohdintatehtäviä, sekä soveltavia tehtäviä. Keskustelutehtävissä osallistujat lähettivät oman kommenttinsa annettuun tehtävään, sekä kommentoivat muiden osallistujien ajatuksia. Pohdintatehtävissä opettajille annettiin kysymys mietittäväksi, mutta omaa pohdintaa ei tarvinnut palauttaa verkkoympäristöön. Soveltavissa tehtävissä edellytettiin kyseisen teeman videoluennoista saatujen tietojen hyödyntämistä tai soveltamista omien kokemusten pohjalta. Soveltavassa osuudessa opettajat suunnittelivat ja toteuttivat ongelmalähtöisen opetuskokeilun oman opetusryhmän kanssa. Toteutuksen jälkeen opetuskokeilusta tehtiin raportti ja kokemusta reflektoitiin yhdessä muiden osallistujien kanssa kurssialueella. Teoriaosuus voitiin suorittaa esimerkiksi ilman omaa opetusryhmää, kun taas soveltavassa osuudessa oman opetusryhmän kanssa toteuttava opetuskokeilu, raportointi ja reflektointi oli suorituksen edellytyksenä. Koko verkkokurssin suorittaminen sisälsi yhteensä 50 tehtävää, joista teoriaosuuteen kuului 40 tehtävää ja 10 tehtävää soveltavaan osaan. 
Taulukko 2. Verkkokurssin sisältämien aktiviteettien lukumäärät

\begin{tabular}{llllllll}
\hline & Ohjeet & Luento & Keskustelu & Pohdinta & Soveltava & $\begin{array}{l}\text { Testaa } \\
\text { tietosi }\end{array}$ & Opetuskokeilu \\
\hline Yhteensä & 3 & 26 & 3 & 3 & 6 & 7 & 2 \\
\hline
\end{tabular}

Koko verkkokurssin suorittaminen sisälsi yhteensä 50 tehtävää, joista teoriaosuuteen kuului 40 tehtävää ja 10 tehtävää soveltavaan osaan.

\subsection{Aineisto ja analyysi}

Tutkimukseen osallistuneet opettajat $(\mathrm{N}=58)$ suorittivat täydennyskoulutusohjelman ensimmäistä osaa syksyllä 2019 MOOC-verkkoympäristössä (Massive Open Online Course). MOOC-ympäristön alustana on Blackboard Open LMS, joka pohjautuu Moodleen. Koska MOOC-ympäristöltä edellytetään, että verkkokursseja voidaan toteuttaa automatisoidusti ilman opettajaa, on MOOC-ympäristöissä yleensä Moodlea kattavammat valikoimat työkaluja ja lokitietoja. Esimerkiksi tutkittava MOOC-ympäristö3 tallensi yksilöllisesti päivämäärän ja kellonajan jokaiselle napin painallukselle. Näin ollen avatut linkit voidaan näyttää esimerkiksi sinisen värin sijasta harmaalla ja tehdyt tai tekemättömät tehtävät voidaan näyttää osallistujille erilaisina. Toisaalta lokitiedot mahdollistavat, että käyttäjien navigointia ja tehtävien suorittamista voidaan jälkikäteen tutkia.

Tässä tutkimuksessa rajauduttiin tarkastelemaan Aktiviteettien suoritus -tietoja eli kurssiosallistumista ja lokitietoja. Näissä tiedoissa on kirjattuna tehtävien suorittamisen päivämäärä ja kellonaika sekunnin tarkkuudella. Verkkokurssin osallistujia informoitiin verkkokurssilla tehtävästä tutkimuksesta ja siitä, mitä tietoja kerätään ja miten tietoja käytetään (koulutuksen kehittäminen ja tutkimus). Suostumus tutkimukseen osallistumisesta kerättiin kyselytutkimuksen yhteydessä. Tutkimukseen osallistuminen oli vapaaehtoista. Osallistujilla oli oikeus peruuttaa tutkimukseen osallistumisensa koska tahansa syytä ilmoittamatta ja ilman seurauksia. Lokitietojen tarkastelusta ei synny tunnistamiseen liittyvää haittaa. Lokitietojen tarkastelusta ei ole välitöntä hyötyä yksittäisille osallistujille, mutta tutkimuksen avulla täydennyskoulutusta voidaan kehittää ja laajemmalla tasolla tulokset voivat antaa tutkimukseen perustuvia kehittämisideoita muihin täydennyskoulutusohjelmiin.

\footnotetext{
${ }^{3}$ Aineistonkeruun aikana käytettiin Blackboard Open LMS 3.5 Maintenance Pack 2 versiota.
} 
Koko verkkokurssin suorittamiseen kulunut aika määritettiin vertaamalla ensimmäisen ja viimeisen aktiviteetin suoritusaikoja. Yksittäisen aktiviteetin suorittamiseen kulunut aika määritettiin laskemalla erotus kahden peräkkäisen aktiviteetin suoritusaikojen välillä. Mikäli seuraava aktiviteetti oli suoritettu yli 3 tunnin kuluttua laskettiin ne suoritetuiksi eri kirjautumiskerralla. Kolmen tunnin raja-arvoon päädyttiin alustavan analyysin perusteella, sillä vaikka yhden tehtävän tekemiseen kului osallistujalta tyypillisesti alle tunti, niin tietyillä soveltavilla tehtävillä ja pohdintatehtävillä tehtävään käytetty aika oli järjestelmällisesti huomattavasti suurempi. Kun tarkastelimme näitä ns. työläämpiä tehtäviä ja otimme tarkasteluun vain ne osallistujat, jotka olivat edenneet muita hitaammin myös muissa tehtävissä, päädyimme arvioon, että vaativampiin tehtäviin on käytetty aikaa noin 2 tuntia. Ottaen huomioon, että yhden tehtävän tekemiseen kuluvan keskimääräinen aika oli alle tunnin, päädyimme valitsemaan raja-arvoksi kolme tuntia. Raja-arvon määrittäminen oli tarpeen, jotta voitiin tarkastella, kuinka monta kertaa verkkokurssialueelle on kirjauduttu tehtäviä tekemään, kuinka monta tehtävää on tehty kerrallaan ja kuinka kauan tehtävien tekemiseen on käytetty aikaa. Raja-arvon avulla voidaan myös nähdä, minkä tehtävän kohdalla tehtävien tekeminen on jätetty kesken ja jatkettu toisena ajankohta. Tuloksissa keskiarvoa on käytetty tyypillisen suorituksen kuvaamiseen ja vaihtelua keskihajonnan sekä pienimmän että suurimman arvon avulla.

Verkkokurssin sisällön vaikutusta suorituskäyttäytymiseen tarkasteltiin tutkimalla tehtäviin kulunutta aikaa tehtävätyypeittäin (vrt. Taulukot 1 ja 2). Suoritusaikojen avulla tarkasteltiin tiettyyn tehtävätyyppiin kulunutta aikaa ja tehtävätyypin yhteyttä yhtenäisen opiskelun keskeyttämiseen. Erityisenä kiinnostuksen kohteena olivat videopohjaiset luennot, sillä videoiden kestoa voitiin verrata tehtävän suorittamiseen käytettyyn aikaan. Yhteydet videon keston, tehtävään käytetyn ajan ja opiskelun keskeyttämisen välillä laskettiin Pearsonin korrelaation avulla. 


\section{Tulokset}

\subsection{Kuinka matematiikan opetuksen täydennyskoulutusverkkokurssi tyypillisesti suoritettiin?}

Kurssipudokkuus. Ensimmäisenä analysoitiin verkkokurssin tehtävien suoritusmäärien kehitystä. Suorittajamäärät laskivat verkkokurssin edetessä niin, että voimakkainta verkkokurssin keskenjättäminen oli soveltavassa osassa, jossa keskenjättäjien määrät kasvoivat suhteessa teoriaosaan (Kuva 2).

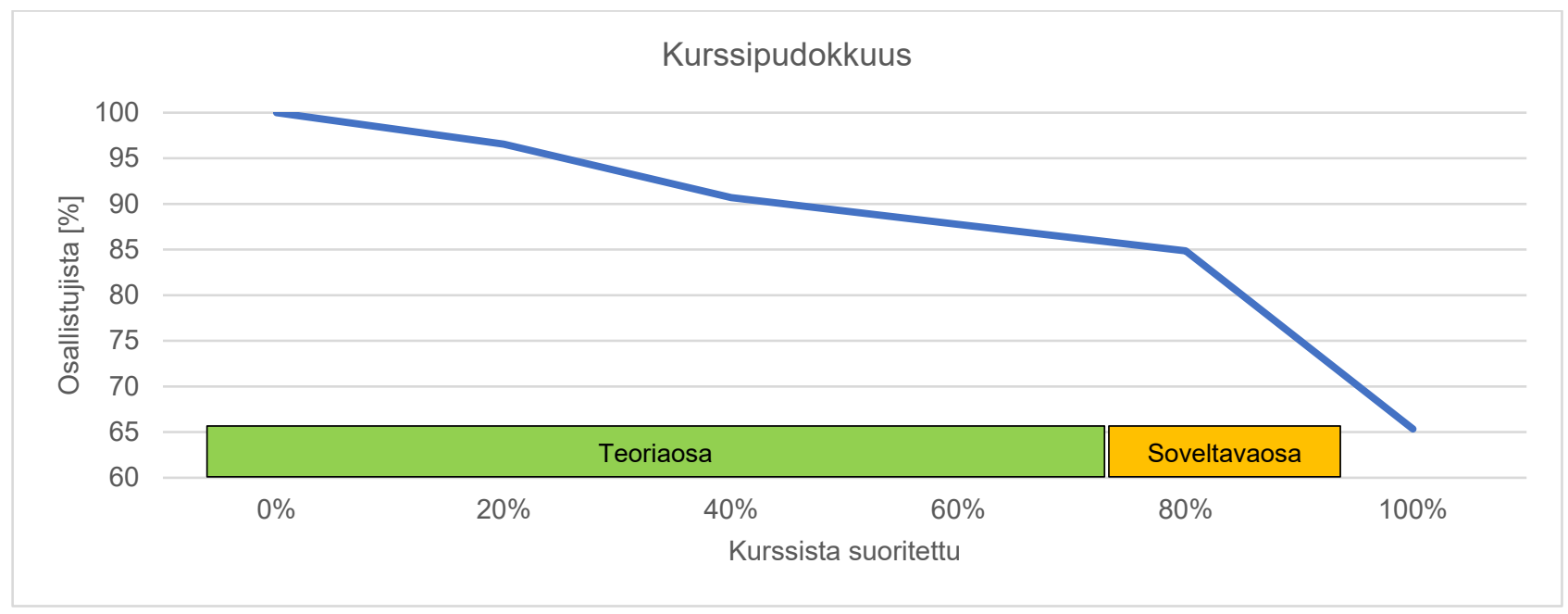

Kuva 2. Tutkimukseen osallistuneista opettajista $(N=58) 81 \%$ suoritti teoriaosan ja $59 \%$ koko verkkokurssin

Kurssikuormitus. Seuraavaksi tarkasteltiin verkkokurssin suorittamiseen kuluvaa kokonaisaikaa. Teoriaosa suoritettiin keskimäärin 63 vuorokaudessa (n. 2 kk) ja koko verkkokurssi 103 vuorokaudessa (n. 3 kk). Teoriaosa oli monessa mielessä kevyempi suorittaa kuin soveltava osuus. Soveltavan osuuden suorittamiseen sisältyi muun muassa oman opetusryhmän kanssa toteutettava opetuskokeilu. Soveltavaan osuuteen sisältyvän opetuskokeilun suunnittelun, toteutuksen ja raportoinnin havaittiin hidastavan verkkokurssin nopeaa suorittamista ja lisäävän suoritusaikaa noin kuudella viikolla (1,5 kk).

Tehtäväkuormitus. Suoritusaikojen perusteella voitiin laskea tehtävien tekemiseen käytetty keskimääräinen aika. Jotta tehtävien suoritusajat ovat vertailukelpoisia, analyysissä keskitytään vain niiden opettajien $(\mathrm{N}=34)$ suorituksiin, jotka suorittivat verkkokurssin kokonaisuudessaan. Näin vertailtavat suoritusajat ovat lähtöisin samoilta henkilöiltä läpi analyysin. Osallistujat tekivät keskimäärin 4,6 
tehtävää yhdellä kirjautumiskerralla ja yhteen tehtävään kului keskimäärin aikaa 1015 minuuttia (Kuva 3).

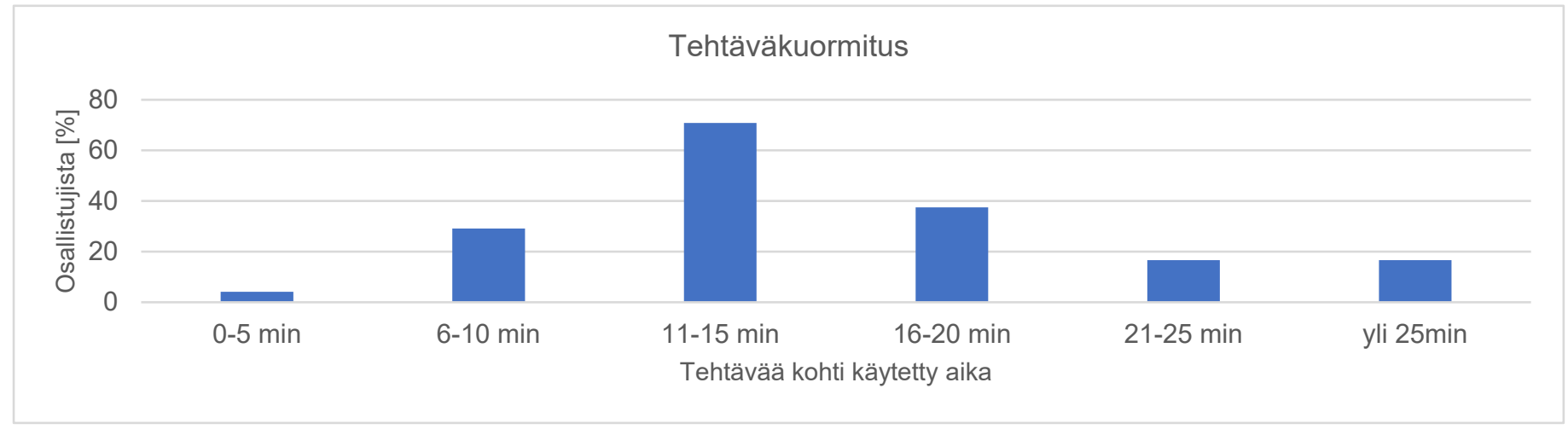

Kuva 3. Koko verkkokurssin suorittaneet opettajat ( $N=34$ ) käyttivät yhteen tehtävään tyypillisesti opiskeluaikaa 10-15 minuuttia

Tehtäviin kïnnittyminen. Yhdellä kirjautumiskerralla tehtiinn useimmiten useampi tehtävä, sillä kirjautumiskerroista $18 \%$ sisälsi yhden ja 82 \% useamman tehtävän tekemisen kerralla. Mikäli tehtäviä suoritettiin enemmän kuin yksi kerrallaan niin, yhdellä kirjautumiskerralla tehtiin keskimäärin 5,8 tehtävää. Kuvaan 4 on havainnollistettu yhdellä kirjautumiskerralla tehtyjen tehtävien lukumääriä. Myös yksittäisellä kirjautumiskerralla suoritettujen tehtävien tekemisessä oli havaittavissa yksilöllisiä eroja, mutta useimmiten tehtäviä tehtiin alle kymmenen kerrallaan.

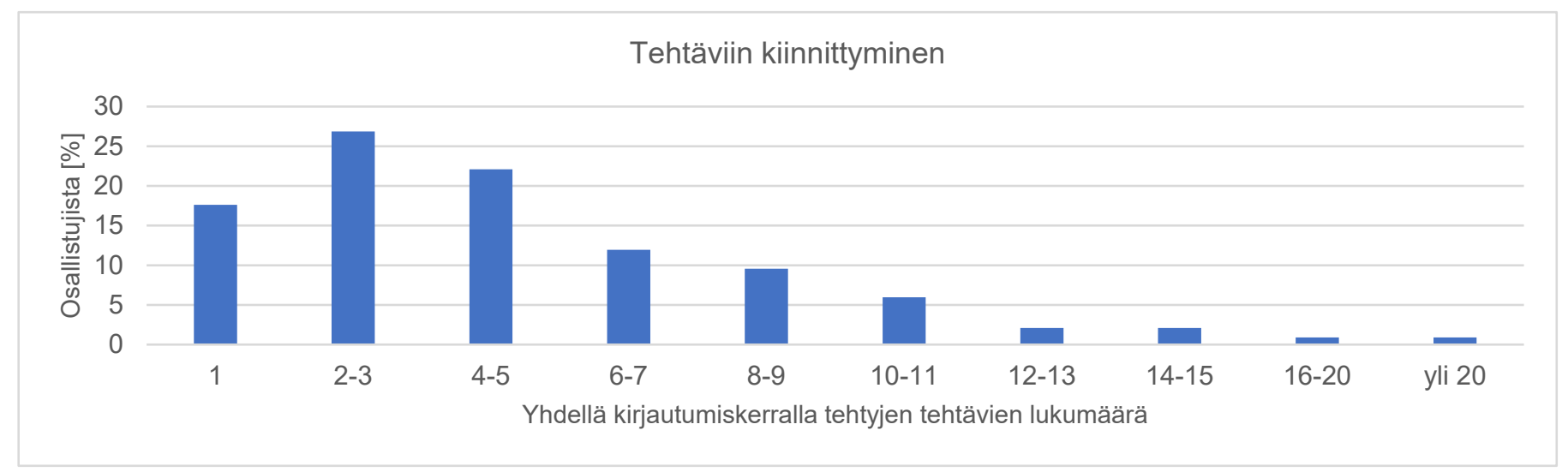

Kuva 4. Koko verkkokurssin suorittaneet opettajat $(\mathrm{N}=34)$ tekivät yhdellä kirjautumiskerralla tyypillisesti 2-10 tehtävää kerrallaan

Yhtenäinen opiskeluaika. Yhtenäinen opiskeluaika oli joka kolmannella puoli tuntia tai alle ja yli $50 \%$ osallistujista yhtenäinen opiskeluaika vaihteli 1-3 tunnin 
välillä. Yli neljän tunnin käyttäminen tehtävien tekemiseen kerralla oli marginaalista. Mikäli kirjautumiskerralla tehtiin useampi kuin yksi tehtävä, tehtävien tekemiseen käytettiin keskimäärin 71 minuuttia kerrallaan. Kuva 5 havainnollistaa vaihtelua yhtenäisen opiskeluajan suhteen.

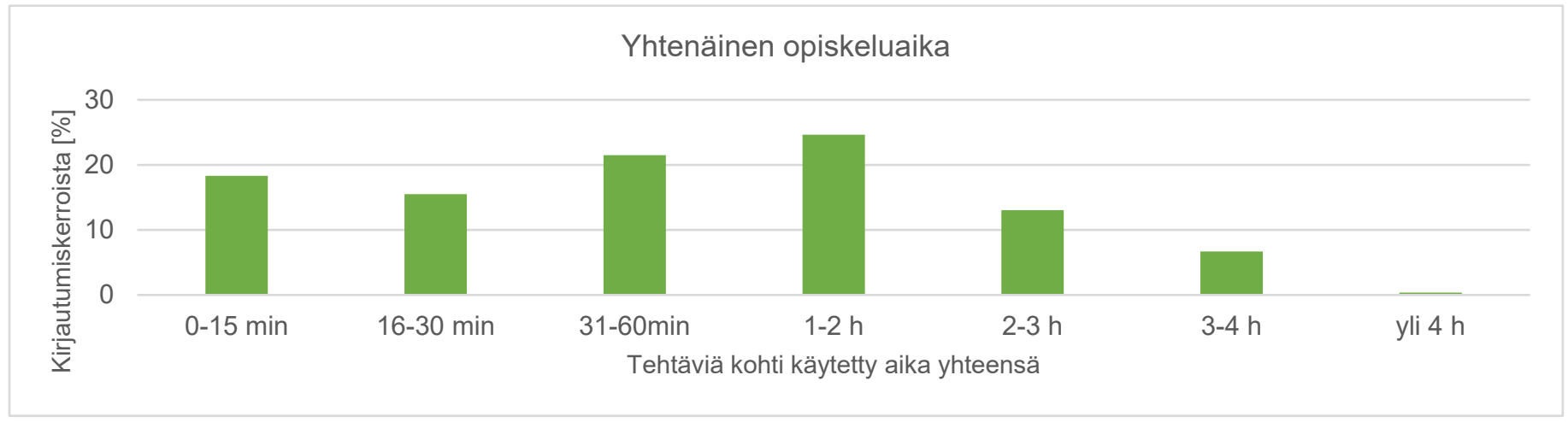

Kuva 5. Koko verkkokurssin suorittaneet opettajat ( $N=34)$ käyttivät opiskeluun aikaa tyypillisesti 1-2 tuntia, yhdellä kirjautumiskerralla

Yhtenäinen opiskeluaika oli joka kolmannella puoli tuntia tai alle ja yli $50 \%$ osallistujista yhtenäinen opiskeluaika vaihteli 1-3 tunnin välillä. Yli neljän tunnin käyttäminen tehtävien tekemiseen kerralla oli marginaalista.

\subsection{Millaisia yksilöllisiä eroja oli havaittavissa verkkokurssin suorittamisessa?}

Vaihtelu verkkokurssin suoritusajassa. Siinä missä keskiarvot kuvaavat tyypillistä suoritustapaa, muiden tunnuslukujen avulla voidaan tehdä päätelmiä suoritusten yksilöllisistä eroista (mm. keskihajonta ja minimi- sekä maksimiarvo). Samalla kun teoriaosuus suoritettiin keskimäärin 63 vuorokaudessa oli osallistujien välinen keskihajonta 45 vuorokautta (Taulukko 3). Tämä tarkoittaa, että suoritusajat vaihtelivat4 tyypillisesti 18 ja 108 vuorokauden välillä (vaihtelua siis 2,5 viikosta 3,5 kuukauteen). Vaihtelu pysyi sen sijaan melko samana, vaikka osallistujat suorittivat koko verkkokurssin. Tämä tarkoittaa, että omassa opetuksessa toteutettava opetuskokeilu ei lisännyt vaihtelua.

\footnotetext{
${ }^{4}$ Tulkinnassa hyödynnetään empiiristä 68-95-99.7 sääntöä, jonka perusteella 68\% tapauksista on yleensä ensimmäisen "keskihajonta-askeleen" päässä keskiarvosta. Näin ollen säännön mukaisesti suurin osa aineistossa esiintyvästä vaihtelusta sijoittuu keskiarvon molemmin puolin keskihajonnan mittaiselle etäisyydelle. Säännön kehitti ranskalainen matemaatikko Abraham de Moivre 1700-luvulla.
} 
Taulukko 3. Vaihtelu teoriaosan ja koko verkkokurssin suoritusajoissa ( $N=34$ opettajaa)

\begin{tabular}{llll}
\hline & Minimi & Keskiarvo/-hajonta & Maksimi \\
\hline Teoriaosuus suoritettu aikavälillä [vuorokautta] & 4 & $63 / 45$ & 179 \\
\hline Koko verkkokurssi suoritettu aikavälillä [vuorokautta] & 20 & $103 / 46$ & 195
\end{tabular}

Vaihtelu kirjautumiskerroissa. Yksilöllisiä eroja oli havaittavissa verkkokurssiin käytetyn ajan lisäksi myös osallistujien kirjautumiskäyttäytymisessä (Taulukko 4). Ääripäitä tarkastelemalla havaittiin, että vähimmillään verkkokurssi suoritettiin viiden ja enimmillään 24 kirjautumiskerran aikana. Tyypillinen vaihtelu kirjautumiskerroissa oli 7-15. Niiden kirjautumiskertojen kokonaismäärä, jolloin osallistujat tekivät vain yhden tehtävän, vaihteli tyypillisesti 1-5 välillä. Kun taas niiden kirjautumiskertojen kokonaismäärä, jolloin tehtiin useampi tehtävä, vaihteli tyypillisesti 2-10 tehtävän välillä. Kirjautumiskertojen lukumäärällä ja kirjautumisen aikana tehtyjen tehtävien välillä on luonnollisestikin yhteys. Mikäli osallistuja suoritti verkkokurssin vähillä kirjautumiskerroilla, tuli hänen tehdä useampia tehtäviä kerrallaan ja päinvastoin.

Taulukko 4. Vaihtelu kirjautumiskertojen kokonaismäärässä ( $N=34$ opettajaa)

\begin{tabular}{llll}
\hline & Minimi & Keskiarvo/-hajonta & Maksimi \\
\hline Kirjautumiskertoja kokonaismäärä & 5 & $11 / 4$ & 24 \\
\hline Kirjautumiskerrat, jolloin teen yhden tehtävä & 1 & $3 / 2$ & 13 \\
\hline Kirjautumiskerrat, jolloin teen useamman tehtävän & 2 & $6 / 4$ & 25 \\
\hline
\end{tabular}

Vaihtelu tehtävïn ja verkkokurssiin käytetyssä ajassa. Aiemmissa tarkasteluissa havaittiin yksilöllisiä eroja tehtävien tekoon käytetyn ajan ja yhdellä kirjautumiskerralla tehtyjen tehtävien määrän suhteen. Taulukkoon 5 on kuvattu verkkokurssin osallistujien ääripäät suhteessa koko verkkokurssiin sekä yksittäiseen tehtävään käytettyyn aikaan. Tyypillisesti yhtä tehtävää kohti käytetty aika vaihteli 921 minuutin välillä ja koko verkkokurssiin käytetty aika 6-14 tunnin välillä.

Taulukko 5. Vaihtelu tehtäviin ja verkkokurssiin käytetyssä kokonaisajassa ( $N=34$ opettajaa)

\begin{tabular}{llll}
\hline & Minimi & Keskiarvo/-hajonta & Maksimi \\
\hline $\begin{array}{l}\text { Käytän aikaa yhden tehtävän } \\
\text { tekemiseen [minuuttia] }\end{array}$ & 5 & $15 / 6$ & 26 \\
\hline $\begin{array}{l}\text { Käytän aikaa koko verkkokurssiin } \\
\text { [tuntia] }\end{array}$ & 4 & $10 / 4$ & 21 \\
\hline
\end{tabular}


Yksittäiseen tehtävään käytetty aika oli likimain suoraan verrannollinen koko verkkokurssin suorittamiseen käytetyn ajan suhteen. Osallistujien kesken oli havaittavissa suuria eroja yksittäiseen tehtävään käytetyn ajan suhteen, jolloin myös koko verkkokurssin opiskeluun investoitu aika eroaa merkittävästi ääripäiden välillä. Esimerkiksi koko verkkokurssiin käytetty opiskeluaika oli yli viisinkertainen ääripäiden välillä.

\subsection{Kuinka tehtävätyypit vaikuttivat verkkokurssin suorittamiseen?}

Tehtävätyypin vaikutus yhtenäiseen opiskeluun. Tehtävien suoritusajankohtien perusteella voidaan myös selvittää, minkä tehtävän kohdalla opiskelu on keskeytynyt ja siirtynyt toiseen ajankohtaan. Kuvasta 6 voidaan havaita, että ohjeita jätetään harvimmin toiseen opiskelukertaan. Testaa tietosi -kyselyt keskeyttivät yhtenäisen opiskelun yhtä harvoin kuin videoluennot. Itse tuotettua tekstiä vaativissa tehtävissä, todennäköisuus sille, että tehtävä tehdään myöhemmin, kasvoi. Esimerkiksi pohdintatehtävissä keskimäärin noin 45 \% jätti tehtävän tekemisen myöhempään ajankohtaan. Toisaalta tulos saattaa indikoida oppimisen näkökulmasta hedelmällistä prosessia, sillä pohdintatehtävissä osallistujien tuli syventää pohdintaansa videoissa esitetyistä näkökulmista.

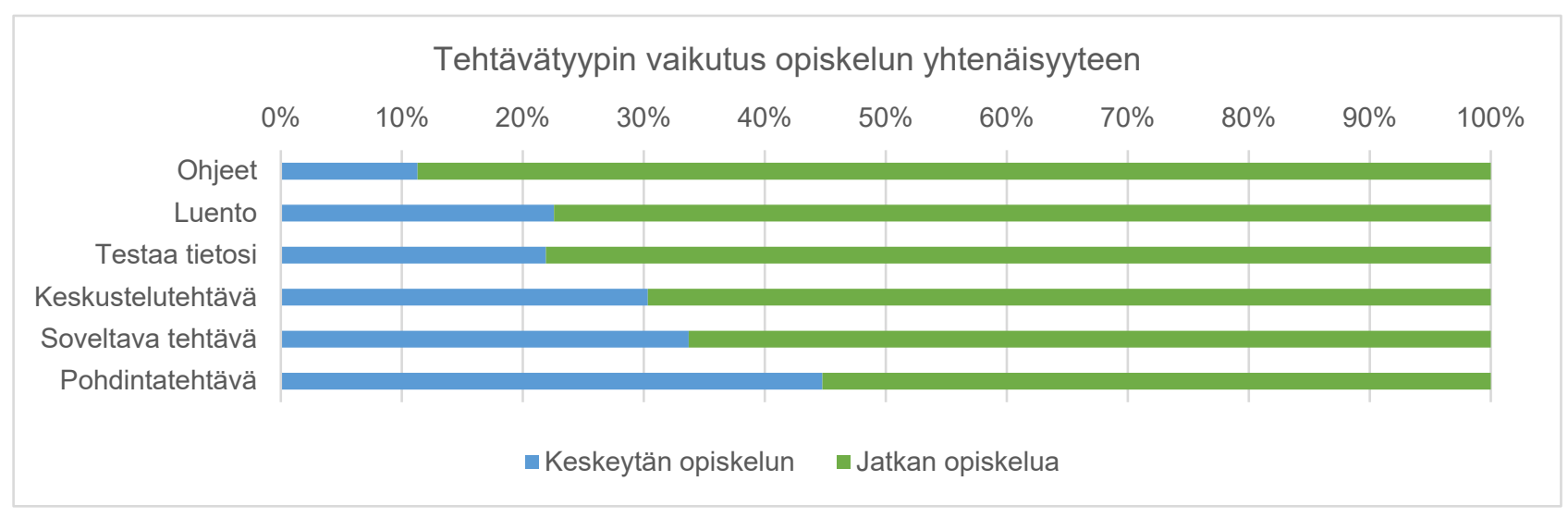

Kuva 6. Yhtenäisen opiskelun jatkaminen ja keskeyttäminen tehtävätyypeittäin

Videoiden ja opiskelun välinen yhteys. Analyysissä verrattiin videoiden kestoa suhteessa tehtävään käytettyyn aikaan sekä näiden aikamääreiden suhdetta tehtävien teon keskeytymiseen (Kuva 7). Siinä missä kuva 6 osoittaa, että videoluentojen kohdalla yhtenäinen opiskelu keskeytyi tyypillisesti 23 \% opiskelukerroista, kuva 7 antaa tarkempaa tietoa videoiden katselusta. Kuvasta voidaan havaita, että 
esimerkiksi videoluennon 3 kohdalla tehtävään käytetty aika on vähemmän kuin videon pituus (oranssi viiva jää sinisen palkin alapuolelle). Tämä tarkoittaa, että videon katsomiseen käytettiin keskimäärin vähemmän aikaa kuin itse video kestää eli toisin sanoen kyseistä videota ei ole tyypillisesti katsottu loppuun saakka.

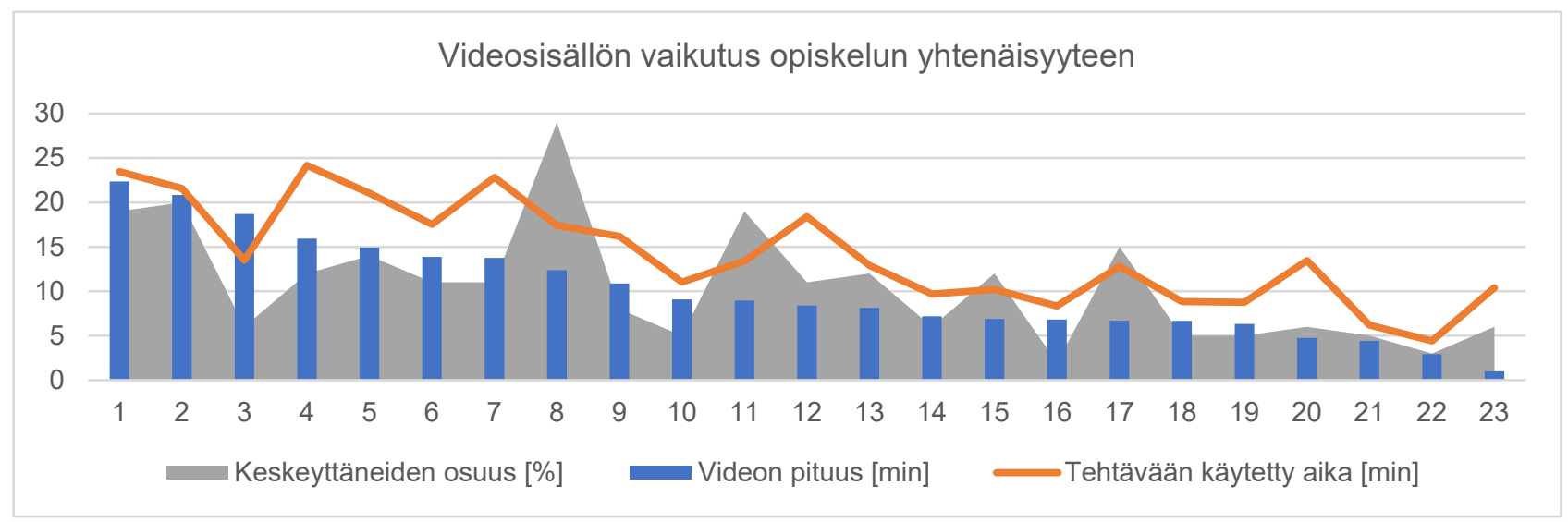

Kuva 7. Videon pituuden vuorovaikutus tehtävään käytettyyn aikaan ja tekemättä jättämiseen.

Harmaat piikit videoiden 8, 11, 15 ja 17 kohdalla tarkoittavat, että trendi poikkeaa tavanomaisesta. Näiden videoiden kohdalla opiskelu useimmiten keskeytyi ja tehtävien tekeminen jätettiin usein toiseen opiskelukertaan. Trendi poikkeaa myös videon 3 kohdalla, jossa harmaa piikki on toisinpäin. Se tarkoittaa, että yhtenäistä opiskelua on jatkettu keskimääräistä paremmin. Mielenkiintoista tuloksessa on se, että kyseessä on juuri video 3, jota ei tyypillisesti katsottu loppuun saakka. Tulos tarkoittaa sitä, että vaikka osallistujat ovat jättäneet tämän videon kesken, he ovat keskimääräistä paremmin jatkaneet opiskelua seuraavaan tehtävään. Videoiden 4, 7, 12, 17, 20, 23 kohdalla on taas piikki (oranssi viiva). Se tarkoittaa, että kyseisiin videoihin on käytetty videon keston lisäksi keskimääräistä enemmän aikaa.

Havaintojen tarkempi tarkastelu osoittaa, että videon pituus korreloi tehtävän tekemiseen käytetyn ajan kanssa $(\mathrm{r}=.806, \mathrm{p}<.01)$, tehtävän tekemiseen kuluva aika korreloi keskeyttämisen kanssa $(\mathrm{r}=.624, \mathrm{p}<.01)$ samoin kuin videon pituus $(\mathrm{r}=.538$, $\mathrm{p}<.01)$. Tuloksen perusteella voidaan sanoa, että mitä pidempi video on, sitä todennäköisemmin verkko-opiskelu keskeytyy. Kun tulosta verrataan kuvan 6 tuloksiin on todennäköistä, että keskustelutehtävät, soveltavat tehtävät ja pohdintatehtävät koetaan myös aikaa vieviksi. Näin ollen tulokset voisi kiteyttää seuraavasti: mitä työläämpänä yksittäinen verkkotehtävä koetaan, sitä todennäköisemin verkko-opiskelu keskeytyy. 


\section{Keskustelu: lokitiedoista hyötyä verkkokurssien \\ kehittämiseen ja opiskelutapojen tunnistamiseen}

Tutkimuksessa tarkasteltiin lokitietojen avulla, kuinka opettajat suorittavat täydennyskoulutuksen verkkokursseja MOOC-verkkoympäristössä. Tällä hetkellä lokitietoja käytetään pääasiassa järjestelmän toiminnan ylläpitämiseen, jotta järjestelmä erottaa käyttäjäkohtaisesti esimerkiksi tekemättömät tehtävät tehdyistä. Vaikka lokitiedot mahdollistavat verkkokäyttäytymisen tutkimuksen, on niitä hyödynnetty verkko-oppimisen ja opetuksen tutkimuksessa vähän.

Aineiston perusteella näyttäisi siltä, että mitä työläämpänä tai aikaa kuluttavampana verkkotehtävän tekeminen koetaan, sitä todennäköisemmin yhtenäinen verkko-opiskelu keskeytyy. Ohjeet, videot ja kyselyt keskeyttävät opiskelun harvemmin kuin soveltavat tehtävät, keskustelu- tai pohdintatehtävät. Tutkittavassa verkkokurssissa tehtävät oli järjestetty siten, että opiskeltavasta teemasta oli useita videoita, joiden päätteeksi tuli joko pohdintatehtävä, keskustelutehtävä tai testaa tietosi -kysely. Tutkimustuloksemme osoittavat, että osallistujat jatkavat yleensä opiskelua uuteen aiheeseen kyselyn jälkeen, kun taas pohdinta- ja keskustelutehtävät usein katkaisivat opiskelun ja osallistujat jatkoivat verkko-opiskelua toisena ajankohtana. Tulos on oppimisprosessin näkökulmasta mielenkiintoinen ja se selittyy mahdollisesti tehtävien kuormittavuudella tai niihin kuluvalla ajalla. Mikäli osallistuja arvioi, että kyselyyn vastaamiseen ei mene pitkään hän suorittaa sen heti, kun taas pohdintatehtävän kohdalla saatetaan kokea, että tehtävä vaatii syventymistä ja siten enemmän aikaa, jolloin tehtävien teko keskeytyy helpommin. Ajan ja kuormittavuuden välillä on havaittu yhteys MOOC-ympäristössä (Champaign ym., 2014). Keskeytys pohdintatehtävissä saattaa johtua myös siitä, että asioita halutaan pohtia ja "jättää hautumaan" ennen vastaamista, mikä voikin oppimisen kannalta olla osoitus niin kutsutusta hedelmällisestä ponnistelusta (engl. productive struggle, ks. Champaign ym., 2014 ja Gardner \& Brooks, 2018, s. 160). Videoluentojen keston ja keskeyttämisen välinen yhteys puoltaa kuitenkin sitä, että keskeyttämisen taustalla saattaa olla tehtävän kuormitus tai siihen kuluva aika. Tulosten perusteella mitä pidempi videon kesto on, sitä todennäköisemmin yhtenäinen opiskelu keskeytyy. Lyhyen videon katsomisen jälkeen osallistuja siirtyy katsomaan seuraavaa videota, kun taas pidemmän videon kohdalla todennäköisyys tehtävien tekemisen keskeyttämiselle kasvaa. DeBoerin ja Breslowin tutkimus (2014) osoitti, että MOOC-kurssissa menestymistä ennakoi paremmin kurssivideoiden välissä tapahtuvat aktiviteetit kuin itse kurssivideoiden katseluun käytetty aika. 
Mikäli tämä pitää paikkansa, ja katselun keskeytyksen jälkeinen aika hyödynnetään hedelmällisiin oppimisponnisteluihin, voi tällaisessa ympäristössä tapahtunut katselun keskeytys olla signaali "hyvästä" oppimisesta. Aihe edellyttää lisätutkimusta. Opiskeluajan löytäminen suhteessa tehtävien työmäärään on tunnistettu verkkoopiskelun keskeiseksi haasteeksi lukuisissa muissa tutkimuksissa (Rogers, 2000; Berge 2002; Brycki \& Dudt, 2005; Muilenburg \& Berge, 2005; Ali \& Magalhaes, 2008). Myös tutkittavassa täydennyskoulutusohjelmassa osallistujat mainitsivat kiireen tai ajanpuutteen keskeisimmäksi syyksi siihen miksi täydennyskoulutuksesta opitut tiedot ja taidot eivät aina päädy hyötykäyttöön (Koponen, Löfström \& Portaankorva-Koivisto, 2020).

Vaikka osallistujien kokemaa kurssikuormitusta tai tehtävien työmäärää ei lokitiedoista voida suoranaisesti nähdä, voimme tarkastella osallistujien eroja tehtäviin sekä verkkokurssiin käytetyssä ajassa. Tulokset osoittavat, että tehtäviin käytetty aika kumuloituu verkkokurssiin käytetyn kokonaisajan kanssa. Kun nopeassa tahdissa etenevä suorittaa nopeasti kaikki tehtävät on verkkokurssiin käytetty kokonaisaika merkittävästi pienempi kuin toisessa ääripäässä. Hitaammin etenevillä verkkokurssin käytetty kokonaisaika oli enimmillään viisinkertainen nopeisiin suorittajiin nähden. Käytännössä tämä tarkoittaa, että siinä missä nopeasti etenevä suorittaa verkkokurssin esimerkiksi kuukaudessa toisen kurssisuoritus kestää viisi kuukautta. Tätä kautta voidaan melko luotettavasti päätellä, että tehtäviin ja verkkokurssiin käytetyillä ajoilla on todennäköisesti yhteys koettuun työmäärään ja kuormittavuuteen.

Tehtäviin ja verkkokurssiin käytetty aika saattaa heijastella myös erilaisia tapoja opiskella. Opiskelulle saattaa löytyä aikaa harvemmin ja se voi olla luonteeltaan pohdiskelevampaa, kun taas toisella on mahdollisuus edetä kurssitehtävissä nopeaan tahtiin. Kun otetaan huomioon aiemmin kuvattu tulos, jonka mukaan todennäköisyys yhtenäisen opiskelun keskeytymiselle kasvaa osallistujan käyttäessä enemmän aikaa tehtävien tekemiseen, on mahdollista, että pohdiskelevampi oppija kokee tehtävien olevan yksi toisensa jälkeen kuormittavia, jolloin verkkokurssin suorittaminen näyttäytyy työläämpänä kuin muille osallistujille. Näin ollen kirjautumismääristä, ajankohdista ja tehtäviin käytetyistä ajoista suhteessa muihin osallistujiin voi olla mahdollista tunnistaa potentiaaliset kurssipudokkaat. Esimerkiksi jos osallistuja käyttää suhteettoman paljon aikaa yksittäisiin tehtäviin ja hänen on lisäksi vaikea löytää aikaa opiskelulle, on opiskelu todennäköisesti satunnaista pikemmin kuin säännöllistä, tehtävät saatetaan kokea työläinä ja lisäksi verkkokurssisisällöt saattavat 
unohtua ja niihin palaaminen vaikeutuu. Vastaava ilmiö on tunnistettu kansainvälisissä tutkimuksissa: mitä pidemmäksi verkkokurssin suorittamisen kokonaisaika kasvaa sitä suurempi on keskeyttäneiden osuus (Nilsen, 2019).

Tutkimustulosten perusteella täydennyskoulutus suoritettiin nopeammassa ajassa ja koulutuksen keskeyttämisprosentti oli pienempi teoriaosuudessa kuin soveltavassa osuudessa. Teoriaosuus sisälsi pääasiassa videopohjaisia luentoja ja automaattisesti tarkentuvia tehtäviä. Soveltavassa osuudessa osallistujan tuli tehdä omassa opetuksessa opetuskokeilu, raportoida siitä verkkoon ja keskustella kokeilusta muiden osallistujien kanssa. Teoriaosuus voitiin suorittaa esimerkiksi ilman omaa opetusryhmää, kun taas soveltavassa osuudessa oma opetusryhmä oli suorituksen edellytyksenä ja lisäksi aikaa tuli varata opetuskokeilun suunnittelulle, toteutukselle ja reflektoinnille. Teoriaosuus oli siis monessa mielessä kevyempi ja nopeampi suorittaa kuin soveltava osuus. Motivaatiota teoriaosuuden suoritukseen saattoi lisätä myös se, että opettajilla oli mahdollisuus saada todistus täydennyskoulutusverkkokurssin suorituksesta vain teoriaosasta. Vaikka edellytykset ja vaativuus olivat korkeammat soveltavalle osalle kuin teoriaosalle voidaan keskeyttämisprosenttia pitää molemmissa osuuksissa suhteellisen matalana. Tutkittavassa verkkokurssissa keskeyttämisprosentti oli teoriaosuudessa $19 \%$ ja soveltavassa osuudessa $41 \%$.

Tutkimuksemme osoittaa, että lokitiedoista saatavan tutkimustiedon avulla voidaan puuttua useisiin verkko-oppimisen haasteisiin. Lokitiedoista saadaan tietoa oppijoiden yksilöllisistä eroista, joiden tunnistaminen on aiemmin tutkimuksissa todettu haasteelliseksi (Terras \& Ramsay, 2015; Yu, 2015). Osallistujien yksilölliset erot opiskelurytmissä ja tehtävien tekonopeudessa voidaan tunnistaa ja samaa rytmiä suosivat voitaisi ryhmäyttää. Lokitiedoista saadaan tietoa tehtävien tekemiseen käytetyistä ajoista, joilla on todennäköisesti yhteys myös kuormittavuuden kokemukseen. Ajan löytämisen haaste ja kuormituksen kokeminen on todettu merkittävänä haasteena useissa tutkimuksissa (Ali \& Magalhaes, 2008; Berge, 2002, Bryzycki \& Dudt, 2005; Muilenburg \& Berge, 2005; Rogers, 2000). Mikäli kuormittavuuteen tekijät ja ajankäyttöön liittyvät haasteet tunnistetaan, ne saattavat vähentää myös verkkokurssien ongelmakohdaksi tunnistettua keskeyttämistä (Nawrot \& Doucet, 2014; Nilsen, 2019). Siinä missä Yu (2015) kuvaa verkkokurssien eduiksi niiden helppoa saatavuutta ja osallistujien mahdollisuutta palata opetussisältöihin uudelleen, lokitiedot tarjoavat täsmällistä tietoa väitteen totuusarvosta. Lokitiedoista saadaan selville palaavatko osallistujat sisältöihin 
uudelleen, mihin sisältöihin uudelleenpalaaminen kohdistuu sekä milloin ja miten opiskelu tapahtuu. Papachristos ym. (2014) esittävät huolen, että verkkokurssien opetussisältöihin tulisi kiinnittää enemmän huomiota. Lokitiedoista saadaan selville esimerkiksi mitkä opetussisällöt keskeyttävät herkimmin yhtenäisen opiskelun tai millaisia videoita ei tyypillisesti katsota kokonaan.

Tutkimuksemme luotettavuutta lisää se, että analysoitu lokitietoraportti sisälsi sekunnin tarkkuudella tiedon tehtävien suorituksesta. Tätä tietoa voidaan pitää itseraportointia huomattavasti luotettavampana, sillä tutkimukseen osallistuneiden olisi ollut käytännössä mahdotonta itse arvioida tehtäviin käytettyä aikaa tällä tarkkuudella. Sen sijaan on hyvä tiedostaa, että oppija on saattanut tehdä tai ajatella jotain muuta verkossa opiskellessaan, jolloin esimerkiksi tehtäviin kuluva aika kasvaa. Kvantitatiivisen tutkimuksen periaatteiden mukaan mitä suurempi tutkittava lokitietoaineisto on, sitä merkityksettömämpiä yksittäiset poikkeavuudet ovat. Lokitiedoista saatava data kasvaa nopeasti, sillä esimerkiksi tässä tutkimuksessa 58 osallistujan 50 tehtäväsuoritusta sisältää 2900 datapistettä. Toisaalta kvantitatiivisen tutkimuksen periaatteet asettavat myös rajoitteita lokitietotutkimukselle. Esimerkiksi lokitietojen avulla voidaan tutkia osallistujien vuorovaikutuksen määrää ja kestoa verkkoympäristössä, mutta lokitiedoilla ei päästä tutkimaan kohtaamisten laatua. Tässä mielessä kvantitatiivisten ja kvalitatiivisten menetelmien yhdistäminen on hyödyllistä jatkossa. Esimerkiksi juuri vuorovaikutuksen määrä ja laatu on koettu verkkokursseilla haastavaksi (Berge, 2002; Muilenburg \& Berge, 2005; Terras \& Ramsay, 2015; Yu, 2015), joten lokitietojen osoittama vuorovaikutuksen määrä voisi olla lähtökohtana laadulliseen arviointiin.

\section{Tulevaisuusvisio: oppimisprofiilit ja verkkoympäristön kehittäminen tekoälyn avulla}

Kehittämistutkimuksen strategian mukaisesti kuvailemme seuraavaksi, kuinka tuloksia voisi hyödyntää verkkokurssien kehittämiseen. Esitämme vision, jossa lokitiedoista saatavaa tietoa hyödynnetään oppimisprofiilien tunnistamisessa ja oppimisympäristön yksilölliseen muokkaamiseen, ja johon myös tekoälyä sovellettaisi prosessin kehittämiseksi (Kuva 8). 


\section{Oppimisympäristön kehittäminen lokitietojen perusteella}

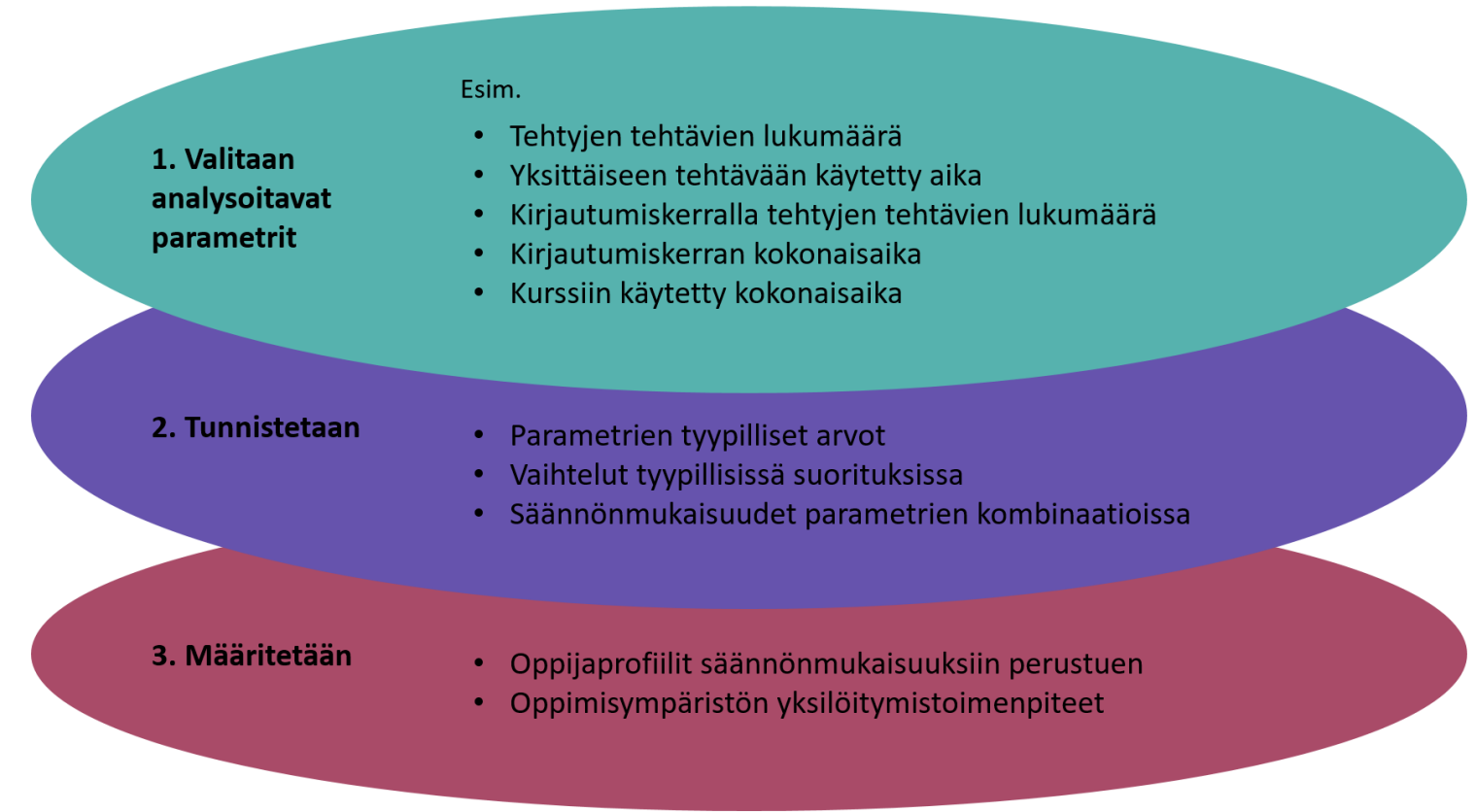

Kuva 8. Lokitietojen avulla verkko-oppijat voidaan profiloida, jolloin verkkoympäristö voisi automaattisesti muokkautua oppijan yksilöllisten opiskelutaipumusten mukaan.

Ensimmäisenä käytössä olevista lokitiedoista valitaan analysoitavat parametrit. Parametrit voivat olla mitä tahansa verkkokäyttäytymiseen liittyvää, joista tietoa on saatavilla ja jotka jollakin merkityksellisellä tavalla liittyvät oppimistoimintaan. Parametrien valinnan jälkeen lasketaan niiden tyyppiarvot ja vaihtelut niiden välillä. Tässä tutkimuksessa analysoituja parametrejä on esitetty kuvassa 8. Näille parametreille laskettiin keskiarvo kuvaamaan tyypillistä suoritusta keskihajonnan sekä pienimmän ja suurimman arvon avulla.

Jo pelkästään tämän analyysin avulla voidaan tehdä päätelmiä tehtävien ja opetussisältöjen kehittämistarpeesta (Kuva 7). Jos järjestelmä ohjelmoidaan analysoimaan automaattisesti videoiden katselukertojen kestoa suhteessa videoiden kestoon, voidaan videoista tunnistaa ne, joita ei tyypillisesti katsota kokonaan. Tällöin oppimisympäristö voisi tiedottaa koulutuksen järjestäjää videoista, joita ei tyypillisesti katsota kokonaan. Mikäli koulutuksen järjestäjällä olisi tällainen tieto, videon ongelmakohtia olisi mahdollista arvioida. Video voidaan editoida, jakaa pienempiin osiin tai poistaa osuuksia. Niin ikään järjestelmä voisi ilmoittaa tehtävistä, joiden tekemiseen osallistujilta kuluu tyypillisesti suhteettoman paljon aikaa, jolloin tehtäväkuormittavuutta on mahdollista arvioida uudestaan. Myös 
erityisen kiinnostavista ja sitouttavista tehtävistä koulutuksen järjestäjän olisi hyvä olla tietoinen.

Seuraava askel onkin kääntää katseet opetussisältöjen sijasta osallistujien erilaisuuteen. Tämä tarkoittaa, että analyysi laajennetaan koskemaan oppijoiden välisiä eroja. Analyysi muuttuu hieman vaativammaksi, sillä tavoitteena on tunnistaa säännönmukaisuudet parametrien yhdistelmässä. Jokainen valittu parametri luo luokittelevan näkökulman oppijoiden erilaisuuteen. Tavoitteena on siis luokitella oppimistapoja ei vain yhden vaan kaikkien käytettyjen parametrien mukaan. Esimerkiksi kirjautumiskertojen lukumäärä ja ajankohta luovat näkökulmia opiskelun rytmittämiseen, kun taas tehtäviin käytetty aika luo näkökulman opiskelun pohdiskelevuuteen. Näin on mahdollista tunnistaa erilaisia oppimisprofiileja. Koska oppimisprofiilit määritetään aineistolähtöisesti, mitä enemmän käyttäjädataa on käytössä, sitä tarkemmin osallistuja luokittuu yhteen, sopivaan oppimisprofiiliin.

Tämän jälkeen verkkoympäristö voidaan ohjelmoida muokkautumaan yksilöllisesti verkko-oppimisprofiilia vastaavaksi. Wangin (2003) mukaan verkkoympäristön yksilöllistäminen on keskeinen verkko-oppimiskokemukseen vaikuttava tekijä (Wang, 2003). Esimerkiksi säännöllisesti kaksi tuntia kerrallaan opiskelevalle järjestelmä voisi muokata tehtävät sellaiseen järjestykseen, että yhden tehtäväpaketin tekemiseen kuluu keskimäärin kaksi tuntia. Osallistujalle, joka vuorostaan opiskelee tyypillisesti koko päivän kerrallaan, järjestelmä voisi kysyä toiveita taukojen määristä ja rytmittää tehtävät aikataulutoiveen mukaisesti. Teknisiä vaikeuksia kohtaavan tai eksyksissä olevan käyttäjän järjestelmä tunnistaisi epätyypillisistä klikkauksista, jolloin järjestelmä voisi tarjota teknistä tai navigointiaapua sitä kaipaavalle. Kun osallistuja käyttää tehtäviin enemmän aikaa suhteessa muihin osallistujiin, järjestelmä voisi automaattisesti keventää tehtäviä, jakaa niitä pienempiin osiin tai kutsua koulutuksen järjestäjän avuksi pohtimaan ratkaisua tilanteeseen. Rodríguez-Ardura ja Meseguer-Artola (2017) ovat esittäneet, että opiskelijan kognitiivisen kuormittumisen huomioiva oppimisprofilointi voisi auttaa tehtävien sopivassa palastelussa ja rytmittämisessä. Oppimisprofilointi voisi auttaa pienryhmien muodostamisessa, jolloin samaa rytmiä suosivat löytäisivät toisensa helpommin.

Rollin ja Wileyn (2016) katsausartikkeli tekoälytutkimuksesta oppimisen kentällä nostaa esille yksilöllisten ratkaisujen tarpeen sekä oppimisanalytiikan mahdollisuudet oppijan oppimiskokemuksen muovaajana. Myös Karsenti (2019) nostaa esille tekoälyn merkityksen esimerkiksi keskeyttämisvaarassa olevien 
oppijoiden tunnistamisessa. Ongelmakohta on kuitenkin se, että prosessi ei itsestään tuota uutta tietoa, esimerkiksi uusia verkko-oppimisprofiileja. Profilointi tarkentuu, mutta profiilit perustuvat alkuperäiseen aineistoon. Tietokone ei tee päätöksiä siitä mitä parametrejä valitaan, miten tunnistetut säännönmukaisuudet tulkitaan, miten oppimisprofiilit määritellään ja millaiset toimenpiteet oppimisympäristön muokkaamiseen määritellään. Jos prosessia vahvistetaan koneoppimisella niin tietokone voi oppia tekemään tämänkaltaisia päätöksiä (Dey, 2016; Jordan \& Mitchell, 2015). Koneoppiminen on eräs tekoälyn muoto, jossa järjestelmä käyttää olemassa olevaa dataa myös omien algoritmien kehittämiseen (Chang, Cohen, \& Ostdiek, 2018). Koneoppiminen soveltuu esitettyyn prosessiin (Kuva 8), sillä oppimisprofiilit määritetään aineistolähtöisesti. Mitä enemmän käyttäjädataa on, sitä paremmin tietokone oppii tunnistamaan säännönmukaisuudet, jolloin profilointi ja sen myötä mahdollisuudet oppimisprosessin räätälöintiin, tarkentuvat. Tämä voi osaltaan helpottaa opettajien täydennyskoulutukseen osallistumisen esteitä (ks. Lavonen \& Mahlamäki-Kultanen, 2016) ja koettuja aikahaasteita (Koponen, Löfström \& Portaankorva-Koivisto, 2020).

Koneoppiminen ei tapahdu ilman ihmisen apua. Koneoppiminen voidaan jakaa kolmeen muotoon; ohjattu oppiminen, vahvistusoppiminen ja ohjaamaton oppiminen, joissa kaikissa ihmisen rooli on erilainen (Dey, 2016). Ensimmäisessä vaiheessa järjestelmää kehitetään ohjattuna oppisena (engl. supervised learning). Tämä tarkoittaa, että koulutuksen järjestäjä tekee päätöksen "oikeasta ratkaisusta" ja kone oppii sen myötä. Jos esimerkiksi järjestelmä tunnistaa, että osallistuja ei ole kirjautunut verkkoympäristöön kahteen viikkoon, järjestelmä kysyy mitä tilanteessa tulisi tehdä. Kun koulutuksen järjestäjä tekee päätöksen, että osallistujalle voisi lähettää sähköpostimuistutuksen koulutuksesta, järjestelmä oppii tunnistamaan missä tilanteissa sähköpostimuistutus on tarpeen. Seuraavassa vaiheessa sovelletaan vahvistusoppimisen periaatetta (engl. reinforcement learning). Tämä tarkoittaa, että järjestelmä toimii eri tilanteissa parhaaksi katsomallaan tavalla. Koulutuksen järjestäjän tehtävänä on valvoa tietokoneen tekemiä päätöksiä. Tämän vaiheen jälkeen järjestelmä toimii jo hyvin itsenäisesti. Viimeisessä ohjaamattoman oppimisen (engl. unsupervised learning) vaiheessa järjestelmän annetaan toiminnan lisäksi myös kehittää itse itseään. Koska esimerkiksi oppimisprofiilien määrittämisen taustalla olevat algoritmit ovat syntyneet aineistolähtöisesti, käyttäjädatan kasvun myötä järjestelmä oppisi parantamaan käytössä olevia profilointialgoritmeja. Tämä 
edellyttää algoritmien säännöllistä arviointia eettisestä näkökulmasta (Morley ym., 2021).

Lopulta keskeistä on, että lokitietoja ja käyttäjädataa hyödynnetään osallistujia kunnioittaen ja heidän oppimistaan edistäen. Mikäli tietoja hyödynnetään oppimistai muussa tutkimuksessa, on sen pohjauduttava tietoon perustuvaan suostumukseen (ellei siitä poikkeamiselle ole erityisiä perusteluja, ks. TENK, 2019). Eettisenä kysymyksenä nousee esille myös se, mitä luokitellaan tai profiloidaan ja miten se tapahtuu; puhutaanko esimerkiksi oppijoiden toimintaan perustuvista oppimisprofiileista (vrt. engl. learning profile esim. Kashive, Powal \& Kashive, 2021) vai oppijaprofiileista (vrt. engl. learner profile, esim. Zou ym., 2017), joka voidaan ymmärtää oppijan henkilökohtaisiin ominaisuuksiin perustuvana luokitteluna. Lopuksi, vaikka esimerkiksi koneoppimisen seurauksena luodut profiilit ja niihin sovelletut oppimispolut perustuvat oppijan jälkiin verkossa, on mahdollista, että yksilö ei tunnista itseään ehdotetuissa valinnoissa, poluissa tai ohjeissa. Oppimistoiminta muodostuu hyvin monesta tekijästä, jotka voivat eri yksilöillä olla erilaisia, vaikka itse toiminta verkossa näyttää olevan samansuuntaista. Tästä syystä on tärkeää miettiä, minkälaisia muita oppimiskokemusta tukevia elementtejä verkkooppimisympäristössä tarvitaan. Oppijoiden osallisuus oman oppimisprosessin muovaamisessa on (edelleen) keskeinen kysymys.

\section{Kiitokset}

Kiitämme LUMA-keskus Suomi -verkostoa, täydennyskoulutuksen kouluttajia ja osallistujia, sekä kahta anonyymia arvioijaa arvokkaasta palautteesta aiempaan käsikirjoitusversioon. Täydennyskoulutuksen toteutuksen arviointi on osa Opetushallituksen rahoittamaa LUMATIKKA-hanketta.

\section{Lähteet}

Adnan, M., \& Anwar, K. (2020). Online Learning amid the COVID-19 Pandemic: Students' Perspectives. Online Submission, 2(1), 45-51.

Ali, G. E., \& Magalhaes, R. (2008). Barriers to implementing e-learning: a Kuwaiti case study. International Journal of Training \& Development, 12(1), 36-53. https://doi.org/10.1111/j.1468-2419.2007.00294.x

Amiel, T., \& Reeves, T. C. (2008). Design-Based Research and Educational Technology: Rethinking Technology and the Research Agenda. Educational Technology \& Society, 11(4), 29-40. 
Anderson, T., \& Shattuck, J. (2012). Design-based research: A decade of progress in education research? Educational Researcher, 41(1), 16-25.

https://doi.org/10.3102/0013189X11428813

Berge, Z. L. (2002). Obstacles to distance training and education in corporate organizations. Journal of Workplace Learning, 14(5), 182-189.

Blömeke, S., Busse, A., Kaiser, G., König, J., \& Suhl, U. (2016). The relation between contentspecific and general teacher knowledge and skills. Teaching and Teacher Education, 56, 3546. https://doi.org/10.1016/j.tate.2016.02.003

Brzycki, D., \& Dudt, K. (2005). Overcoming barriers to technology use in teacher preparation programs. Journal of Technology and Teacher Education, 13(4), 619-641.

Champaign, J., Colvin, K. F., Liu, A., Fredericks, C., Seaton, D., \& Pritchard, D. E. (2014). Correlating skill and improvement in 2MOOCswith a student's time on tasks. In Proceedings of the First ACM Conference on Learning @ Scale (pp. 11-20). ACM, New York.

Chang, S, Cohen, T., \& Ostdiek, B. (2018). What is the machine learning? Phys. Rev. D, 97(5),056009. https://doi.org/10.1103/PhysRevD.97.056009

Chen, H-J. (2010). Linking employees' e-learning system use to their overall job outcomes: An empirical study based on the IS success model. Computers \& Education, 55(4), 1628-1639. https://doi.org/10.1016/j.compedu.2010.07.005

Cheng, B., Wang, M., Mørch, A., Chen, N-S., Kinshuk, J., \& Spector, M. (2014). Research on elearning in the workplace 2000-2012: A bibliometric analysis of the literature. Educational Research Review, 11, 56-72. http://dx.doi.org/10.1016/j.edurev.2014.01.001

Crawford, J., Butler-Henderson, K., Rudolph, J., Malkawi, B., Glowatz, M., Burton, R., ... \& Lam, S. (2020). COVID-19: 20 countries' higher education intra-period digital pedagogy responses. Journal of Applied Learning \& Teaching, 3(1), 1-20.

https://doi.org/10.37074/jalt.2020.3.1.7

DeBoer, J., \& Breslow, L. (2014). Tracking progress: predictors of students' weekly achievement during a circuits and electronics MOOC. In Proceedings of the First ACM Conference on Learning @ Scale (pp.169-170). ACM, New York.

Dey, A. (2016). Machine learning algorithms: a review. International Journal of Computer Science and Information Technologies, 7(3), 1174-1179. https://doi.org/10.3968/6023

Gardner, J., \& Brooks, C. (2018). Student success prediction in MOOCs. User Modeling and UserAdapted Interaction, 28(2), 127-203. DOI: 10.1007/s11257-018-9203-Z

Hsieh, F.-J., Law, C.-K., Shy, H.-Y., Wang, T.-Y., Hsieh, C.-J., \& Tang, S.-J. (2011). Mathematics Teacher Education Quality in TEDS-M: Globalizing the Views of Future Teachers and Teacher Educators. Journal of Teacher Education, 62(2), 172-187. https://doi.org/10.1177/0022487110390819

Herranen, J. K., Aksela, M. K., Kaul, M., \& Lehto, S. (2021). Teachers' expectations and perceptions of the relevance of professional development MOOCs. Education Sciences 11(5), 240. https://doi.org/10.3390/educsci11050240

Jordan, M. I., \& Mitchell, T. M. (2015). Machine learning: Trends, perspectives, and prospects. Science, 349(6245), 255-260. https://doi.org/10.1126/science.aaa8415

Juuti, K., \& Lavonen, J. (2006). Design-Based Research in Science Education: One Step Towards Methodology. NorDiNa, 4, 54-68. https://doi.org/10.5617/nordina.424

Kaiser, G., \& König, J. (2019). Competence Measurement in (Mathematics) Teacher Education and Beyond: Implications for Policy. Higher Education Policy, 32(4), 597-615.

https://doi.org/10.1057/s41307-019-00139-Z

Karsenti, T. (2019). Artificial intelligence in education: The urgent need to prepare teachers for tomorrow's schools. Formation et profession, 27(1), 105-111.

https://doi.org/10.18162/FP.2019.A166 
Kashive, N., Powale, L., \& Kashive, K. (2021), Understanding user perception toward artificial intelligence (AI) enabled e-learning. International Journal of Information and Learning Technology, 38(1), 1-19. https://doi.org/10.1108/IJILT-05-2020-0090

Kervinen, A., Uitto, A., Kaasinen, A., Portaankorva-Koivisto, P., Juuti, K., \& Kesler, M. (2016). Developing a Collaborative Model in Teacher Education - An Overview of a Teacher Professional Development Project. LUMAT International Journal on Math, Science and Technology Education, 4(2), 67-86. https://doi.org/10.31129/LUMAT.4.2.33

Koponen M., Löfström E., \& Portaankorva-Koivisto (2020). "Kïre on". Matematiikan opetuksen täydennyskoulutuksen vaikuttavuus opettajan näkökulmasta [Käsikirjoitus lähetetty julkaistavaksi]. Kasvatustieteellinen tiedekunta, Helsingin ylipisto.

Lavonen, J., \& Mahlamäki-Kultanen, S. (2016). Opettajankoulutuksen kehittämisen suuntaviivoja. Opettajankoulutusfoorumin ideoita ja ehdotuksia). Ministry of Education and Culture Publications 2016:34. Ministry of Education and Culture.

Löfström E., Koponen, M., Salonen, V., \& Aksela M. (2021). Teachers' experiences of e-learning in mathematics teaching in-service training: Two dimensions of meaningful learning [Manuscript submitted for publication]. Faculty of Educational Sciences, University of Helsinki.

Lu, H-P., \& Chiou, M-J. (2010). The impact of individual differences on e-learning system satisfaction: A contingency approach. British Journal of Educational Technology, 41(2), 307-323. https://doi.org/10.1111/j.1467-8535.2009.00937.x

Morley, J., Elhalal, A., Garcia, F., Kinsey, L., Mökander, J., \& Floridi, L. (2021). Ethics as a service: A pragmatic operationalisation of AI ethics. Minds and Machines, 31, 239-256. https://doi.org/10.1007/s11023-021-09563-w

Mailizar, A., Abdulsalam, M., \& Suci, B. (2020). Secondary school mathematics teachers' views on e-learning implementation barriers during the COVID-19 pandemic: The case of Indonesia. Eurasia Journal of Mathematics, Science \& Technology Education, 16(7), 1-9. https://doi.org/10.29333/ejmste/8240

Muilenburg, L. Y., \& Berge, Z. L. (2005). Student barriers to online learning: a factor analytic study. Distance Education, 26(1), 29-48. https://doi.org/10.1080/01587910500081269

Mseleku, Z. (2020). A literature review of E-learning and E-teaching in the era of Covid-19 pandemic. International Journal of Innovative Science and Research Technology 5(10), $588-597$.

Nawrot, I., \& Doucet, A. (2014). Building engagement for MOOC students: introducing support for time management on online learning platforms. In Proceedings of the 23rd International Conference on world wide web (pp. 1077-1082). https://doi.org/10.1145/2567948.2580054

Nilsen, G. S. (2019) Digital Learning Arena. Report of BI Norwegian Business School in collaboration with EdTech Foundry 2015-2019.

Papachristos, N., Vrellis, I., Natsis, A., \& Mikropoulos, T. (2014). The role of environment design in an educational Multi-User Virtual Environment. British Journal of Educational Technology, 45(4), 636-646. https://doi.org/10.1111/bjet.12056

Regmi, K., \& Jones, L. (2020). A systematic review of the factors-enablers and barriers-affecting e-learning in health sciences education. BMC medical education, 2O(1), 1-18.

https://doi.org/10.1186/s12909-020-02007-6

Rodríguez-Ardura, I., \& Meseguer-Artola, A. (2016), What leads people to keep on e-learning? An empirical analysis of users' experiences and their effects on continuance intention.

Interactive Learning Environments, 24(6), 1030-1053.

https://doi.org/10.1080/10494820.2014.926275 
Rodríguez-Ardura, I., \& Meseguer-Artola, A. (2017). Flow in e-learning: What drives it and why it matters. British Journal of Educational Technology, 48(4), 899-915.

https://doi.org/10.1111/bjet.12480

Rogers, P. L. (2000). Barriers to adopting emerging technologies in education. Journal of Educational Computing Research, 22(4), 455-472. https://doi.org/10.2190/4UJE-B6VWA30N-MCE5

Roll, I., \& Wiley, R. (2016). Evolution and revolution in artificial intelligence in education. Journal of Artificial Intelligence in Education, 26, 582-599. https://doi.org/10.1007/s40593-0160110-3

Schmidt, W. H., Blömeke, S., Tatto, M. T., Hsieh, F. J., Cogan, L., Houang, R. T., \& Schwille, J. (2011). Teacher education matters: A study of middle school mathematics teacher preparation in six countries. New York: Teachers College Press, Columbia University.

Schmidt, W. H., Houang, R., \& Cogan, L. S. (2011). Preparing future math teachers. Science, 332(603), 1266-1267. https://doi.org/10.1126/science.1193855

TENK (2019). Ihmiseen kohdistuvan tutkimuksen eettiset periaatteet ja ihmistieteiden eettinen ennakkoarviointi Suomessa. Tutkimuseettisen neuvottelukunnan julkaisuja 3/2019. Luettu 28.8.2021 https://tenk.fi/fi/eettinen-ennakkoarviointi/ihmistieteiden-eettinenennakkoarviointi

Terras, M. M., \& Ramsay, J. (2015). Massive open online courses (MOOCs): Insights and challenges from a psychological perspective. British Journal of Educational Technology, 46(3), 472-487. https://doi.org/10.1111/bjet.12274

Wang, F., \& Hannafin, M. J. (2005). Design-Based Research and Technology-Enhanced Learning Environments. Educational Technology Research and Development, 53(4), 5-23. https://doi.org/10.1007/BF02504682

Wang, Y-S. (2003). Assessment of learner satisfaction with asynchronous electronic learning systems. Information \& Management, 41(1), 75-86. https://doi.org/10.1016/So3787206(03)00028-4

Wang, Y-S., Wang, H-Y., \& Shee, D. Y. (2007). Measuring e-learning systems success in an organizational context: Scale development and validation. Computers in Human Behavior, 23, 1792-1808. https://doi.org/10.1016/j.chb.2005.10.006

Wood, T., \& Berry, B. (2003). Editorial: What does 'design research' offer mathematics teacher education? Journal of Mathematics Teacher Education, 6(3), 195-199.

Wu, H-Y., \& Lin, H-Y. (2012). A hybrid approach to develop an analytical model for enhancing the service quality of e-learning. Computers \& Education, 58, 1318-1338. https://doi.org/10.1016/j.compedu.2011.12.025

$\mathrm{Yu}, \mathrm{C}$. (2015). Challenges and changes of MOOC to traditional classroom teaching mode. Canadian Social Science, 11(1), 135-139. http://dx.doi.org/10.3968/6023

Zou D., Xie H., Wong TL., Wang F.L., Kwan R., Chan W.H. (2017) An Explicit Learner Profiling Model for Personalized Word Learning Recommendation. In: Huang T. C., Lau R., Huang Y. M., Spaniol M., \& Yuen C. H. (eds.) Emerging Technologies for Education. SETE Lecture Notes in Computer Science, 10676. Springer. https://doi.org/10.1007/978-3-319-71084$6 \_58$ 